Viewpoints and Letters to the Editor are published in HortScience to provide Members of the American Society for Horticultural Science an opportunity to share their experiences and comments on matters of concern to horticulturists. These are not statements of official Society policy, nor do they necessarily reflect the views of a majority of the Society's Members.

\title{
Reaffirming Our Land-grant Tradition
}

\author{
Presidential Address ${ }^{1}$
}

\author{
Thomas A. Fretz ${ }^{2}$ \\ ASHS President, 1991-92
}

\begin{abstract}
"Would you please tell me which way I might go from here?" said Alice. "That depends a good deal on where you want to get to," said the cat. "I don't much care where," said Alice. "Then it doesn't matter which way you go," said the cat.
\end{abstract}

\section{Lewis Carroll, Alice in Wonderland}

$$
*
$$

To aid in acquiring and diffusing among the people of the United States useful and practical information on subjects connected with agriculture.

Hatch Act, 1887

I have chosen to address you not as horticulturists but rather as agriculturists. Therefore, I direct my remarks to the broader issue of the land-grant mission and tradition and to what lies ahead as we face the beginning of the 21 st century. Horticulturists should be visionary as we look toward the opportunities and challenges that are before us and our land-grant institutions.

I think we can all agree that American agriculture-and, for our purposes, horticulture-is still a modern-day miracle. It provides the United States and much of the world with fresh and processed fruit and vegetable products for daily consumption, landscape and floral crops for enjoyment, and the technologies that make all of this possible. How did all of this come about, and how do we insure its continued success?

I suggest that land-grant universities have played a very special role in these achievements. Our land-grant universities are among the nation's finest, with many having achieved world-class status and distinction. It is in the laboratories, classrooms, and re-

${ }^{1}$ Presented at the 89th Annual Meeting of the American Society for Horticultural Science, Honolulu, 5 Aug. 1992.

${ }^{2}$ College of Agriculture, Iowa State Univ., Ames.

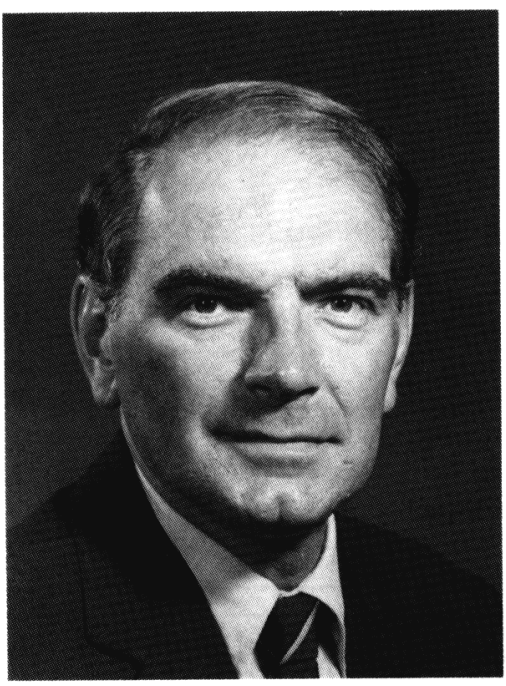

search farms of these universities that we have produced the scientists, teachers, and technicians who transformed American horticulture in the past century. As these great institutions were formed, with their tripartite mission of instruction, research, and public service, there was a zeal to share knowledge generated, for it is knowledge that serves the people and their interests. We are the knowledge providers, and our primary mission must remain that of developing and transferringknowledge. Stated another way, Do we shape change, or does change shape us?

Surely, if there is any reason for concern about the special obligation of our land-grant universities, it is a result of the fact that not all faculty accept or even grasp the premise of this mission. From their creation land-grant institutions were infused with the idea of service to people. Nearly 50 years before the actual writing of the act that would allow these institutions to spring into existence, Thomas Jefferson must have envisioned the land-grant university as he wrote in the charter of the university he was to create-The University of Virginia-that it was to be "an institution in which every branch of knowledge useful at this day is taught in its highest degree.” Justin Morrill's Act of 1862, authoriz- ing the establishment in each state of a land-grant institution, surely must have drawn heavily on this Jeffersonian concept, but with one exception-that these institutions be available to all of the state's citizens, regardless of class or social standing. As a result, public education was to become inclusive not exclusive, practical not theoretical, unconventional not traditional. Over the next 150 years there was a transformation in higher education-I am addressing the products of that transformation-transformation into a model that private and public institutions in the United States and throughout the world now seek to emulate. What better compliment than to be imitated far and wide. The land-grant ethic is said to define much of public higher education. Most if not all other state colleges and universities, including community, regional, and junior colleges, make service to a local clientele an explicit part of their mission. All recognize service, not only as a responsibility and obligation, but a requirement for success.

But how has this transformation come about? What strengths make land-grant institutions so special? The three cornerstones of these institutions are institutional capacity, faculty, and citizen support. Our land-grant universities are comprehensive institutions with institutional strengths that allow for combining basic and applied sciences, traditional and nontraditional disciplines. Through both formal and informal arrangements, these institutions have the ability and wherewithal to deal with complex interdisciplinary issues.

We have built these unique institutions with faculty who rank among the very best. This faculty strength comes from the tradition of hiring and training the very best and brightest, providing them with the best possible facilities and an administrative attitude of nonintervention. This has allowed faculty to pursue their teaching, research, and public service responsibilities without interference.

Of course, the third component of this success has been strong citizen support. Each land-grant university is "a people's university," belonging to the citizens of each state. How many of our colleagues at other institu- 
tions, either public or private, can say the same! This partnership with the people of our states, fostered as a result of our public service efforts, has been long and lasting, for we have responded to the needs of the public by educating their children and providing them with information that affects the quality of their lives and communities.

In my view there are four broad and allencompassing challenges that land-grant universities must address as we move toward the 21 st century if we are going to retain the relationship we have with the citizens of our states and nation and the very special place we occupy in the scheme of higher education.

\section{RESHAPING THE RESEARCH AGENDA}

\section{Enunciating the Mission}

To reshape the agricultural research agenda, we might well begin with the very premise for conducting agricultural research. We need to have clear goals and a sound rationale so that the public, which from both state and federal sources has generously provided our basic fiscal resources, continues to feel that ours is a worthwhile endeavor. I suggest that the beneficiaries of our research efforts are not just the farmers and producers who each year more efficiently produce the world's food, feed, and fiber; the consumer also benefits greatly from the use of tax dollars for agricultural research by having a readily available supply of high-quality, safe, and inexpensive food.

Our publicly funded agricultural research must be oriented toward meeting the needs of the society that provides the basic funding. The benefits derived from support for agricultural research must be articulated to the public by the collective community of scientists, teachers, and those whose primary mission is public service. As we face funding and scientific challenges, we need to develop a clear, unified, convincing message regarding our goal. This, of course, will require that scientists maintain an interest in the issues that are of concern to the public, including sustainability of our natural resources, food safety, water quality, and the environment. We must also be willing to modify our horticultural research agenda to address these needs.

It will become exceedingly important that we effectively communicate the mission, goals, and objectives of our research. Calling our research fundamental or basic and emphasizing its value for what it adds to the body of science is fine to a point, but it won't be enough to maintain support from those who control the public purse strings. Even the most basic scientists, the high-energy physicists, are elaborating to the public the value of the supercollider. Biologists and agricultural scientists must do the same! For an increasing number of scientists, including many in our own community, it is easy to become frustrated when trying to describe the concrete benefits from their research, but tough budget times demand that we clearly and concisely articulate our research objectives and goals. There must be a clear distinction between working toward an ultimate objective of societal interest vs. developing a rationale just to keep a research project going. Clearly society is going to ask and will expect to hear from agricultural scientists in the future.

\section{Expanding Interdisciplinary Programs}

There is an increasing need for expanding collaborative efforts between departments in our colleges and those in other colleges of our universities. We must broaden our vision and erase the old disciplinary boundaries. I continue to be concerned that we fail to see the need to interact and form interdisciplinary teams with colleagues in our own college. Even more rarely do we look outside our colleges of agriculture for collaborations with scientists in biochemistry, microbiology, genetics, computer science, or the social sciences. The tough problems scientists will face in the next decade and beyond will require this broad cooperation between departments across our campuses. No longer can an individual single-handedly solve the many problems we face, nor can a college always provide all the resources or personnel needed.

The barriers that prevent or retard these cooperative efforts must be eliminated in order for the university to better fulfill its mission. Seminars, guest lecturers, and co-advisors for graduate student committees may eliminate these obstructions, and perhaps with the hiring of discipline-oriented scientists in many of our departments we are witnessing the further erosion of these barriers. These interdisciplinary efforts will add a new, refresh-ing dimension to our departments.

Only by forming broad linkages will we be able to move accurately and realistically to identify all of the constraints within our agricultural system. I also want to add that those interdisciplinary teams that I spoke of should not merely be a multidisciplinary lumping together of individuals who "do their own thing," but rather an interdisciplinary synthesis of ideas and viewpoints coming together in a synergistic fashion to solve issues.

\section{Adapting New Technologies}

Perhaps one reason that horticultural (and for that matter agricultural) research is viewed by some as less prestigious is that we often lag behind in adopting new technologies. Biotechnology and computer technologies are two obvious areas that could significantly affect the horticultural community, yet their potential is still just that-potential.

We need to accelerate our use of the tools of biotechnology to develop monoclonal antibody test kits for disease screening, crop identification, and to accelerate the development of pest-resistant hybrids and herbicide-resistant crops. And agricultural scientists are particularly lacking in our use of new com- puter technologies. In the medical sciences, expert systems are becoming the norm; teaching is accomplished with hypertext linkages of graphics and text; interactive videodiscs are used to an increasing degree; and most laboratory equipment is run by computer. Agriculture needs to match medicine's commitment to and application of new computer technology, given that computers and other information technologies can clearly benefit agriculture. In both biotechnology and computer science, we are headed in the right direction, just not fast enough.

\section{Closer Links between Research, Teaching,} and Public Service

My last challenge for the research community is that we return to one of our past strengths-that linkage between research, teaching, and public service. In the area of technology transfer, we all agree that extension plays an important role in the communication of ideas and information in both directions, from the farmer/producer as well as to the farmer/producer.

County extension personnel and especially farmers are perhaps the ultimate integrators and thus should serve as important members of systems research teams. These individuals have the advantage of viewing problems, not with a disciplinary orientation but in a fashion that may identify components of the problem that a group of disciplinary scientists may have overlooked. The involvement of farmers/producers and local extension professionals, particularly in adaptive research, has been successful for international agricultural scientists who practice the farming systems methodology. Shouldn't this approach be adapted and incorporated into our own technology transfer efforts?

The educational portion of this trilogy could be further enhanced by involving our students, both graduate and undergraduate, in research, particularly in systems research projects that grapple with contemporary issues. Students, as we are all fully aware, often gain more through an active learning environment, working as part of a team on a real problem, than by sitting in a classroom passively absorbing a lecture.

\section{RETHINKING COOPERATIVE EXTENSION AND TRANSFER OF TECHNOLOGY}

Throughout our land-grant system, considerable effort is underway to better determine how our public service effort, the cooperative extension system, might be more effective. In fact, a painful adjustment is underway nationwide, as extension struggles to define a mission that will grasp the new realities. How do we return to one of our past strengths, this linkage between research, teaching, and public service?

With extension at the crossroads, facing hard choices and difficult decisions, we must 
look forward to a redefinition of the traditional role and scope of cooperative extension. At the same time, we must look for new organizational models that\&ring faculty from the nontraditional disciplines into productive linkages with extension.

Is it possible that we may see the demise of cooperative extension as we have known it? I believe it highly unlikely. We must, however, find new means of bringing information to the end users. In the past it has been relatively easy to provide practical knowledge from our laboratories and experiment station farms to the farmer/producer, but today's farmers, producers, and the agribusiness community need timely, practical, useful, and readily adaptive information. This is a far more difficult task than many realize and one that could crush extension. We have the capacity to introduce greater use of computers, speed the information flow and assist farmer/producers with optimizing their crop management, yet what can we provide these users in the face of declining markets, increased international competition, and declining and dying rural communities?

There are no quick "fixes" to this problem, but we must rely on our faculty and extension specialists to provide practical, timely assistance to farm families, rural enterprises, producers, and communities in times of stress. If we are successful, our farms that made this country great will again flourish, migration of our youth from the rural communities will slow or cease, and the rural community will thrive again!

This need not be a Herculean challenge but rather will require a bootstraps approach. It will require a recommitment of our land-grant universities to the ideas of public service. This will require all of us to understand, accept, and re-embrace this philosophy. If we are to believe that change is needed and required, then it will take some change on our part. In this decade of change I again ask, Does change shape us, or do we shape change? To continue in our land-grant tradition to serve people, we must first accept the challenge to LISTEN. This process must begin with advisory committees at all levels, the department, college, and university-these committees bring to the table a wealth of experience and wisdom. How often do we sit through an advisory committee meeting, only to wonder who is being listened to? By listening we can regain the confidence and support of consumers, producers, students, alumni, and even environmentalists. In fact, as we reevaluate our commitment as land-grant universities and our role and obligation of public service, we need to engage the entire campus in this need to serve.

\section{REFORMING UNDERGRADUATE EDUCATION}

As we look at needs for undergraduate education in our land-grant universities, we may have reached the heart of the issue. Education is, in fact, our highest calling and it is also an urgent calling, for if we fail at this most primary of our tasks, we will have little to extend and even less to research in the future.

\section{Departmental enrollments}

Negative and even unfair stories about farm practices and the farm crisis have discouraged a generation of youth from pursuing careers in horticulture. Indicative of this is the decline we have witnessed in the enrollments in our colleges of agriculture since 1980, reflected to a great degree in the plant sciences. Enrollments nationwide declined in colleges of agriculture by more than $20 \%$ and in departments of horticulture by as much as $60 \%$, but recent trends indicate that students may be returning. It is estimated that colleges of agriculture are producing only $60 \%$ of the graduates needed to meet the demands of the job market. Recent discussions with several department of horticulture chairs and heads indicate that many of the horticultural industries have more positions available than applicants.

The more successful departments have been developing highly specific and well-coordinated programs to inform high school students about courses, curricula, training/internship opportunities, employment and the excellent future in horticulture and the green industries. It will no longer be possible to attract students by staying on campus and expecting that potential students will enroll as "aggies." There are just too many other disciplines with sophisticated and active recruitment programs designed to attract high school seniors.

Moreover, there are many uninformed individuals who give high school students the impression that horticulture (often because of its relationship to agriculture) is a declining industry, with few jobs and even fewer career opportunities. Nothing could be further from the truth! The horticultural industries have experienced double-digit growth and expansion during the 1980s, and even greater growth is anticipated for the 90s. For these reasons and more, it is important that horticulturists become proactive in their recruitment efforts.

\section{Curriculum and Course Offerings}

It is no longer valid to require that each student in a particular major take the same courses. Much has been accomplished in many departments, but more needs to be done to relax the major course requirements so that students, with assistance and guidance, can design their course of study to meet expected job requirements. This will require an extra effort on the part of the faculty in their counseling efforts. Excellence in counseling will help students to know that their individual needs will receive serious consideration.

Future agriculture students will need to be better trained than their predecessors to meet the job needs of the next century. Moreover, if we are not educating young men and women with either an awareness of or a competence in computer technologies, genetic engineering, biotechnology, etc., we are shirking our re- sponsibility. Additionally, our students must have communication skills and a business thrust in their training to succeed in the job environment. Beyond these skills, students should have an awareness of the issues of the day, including food safety, sustainable agriculture, water quality, and the environmental issues affecting our agricultural and food production systems. These comments are made in the belief that today's students need to be aware of the complexity of modern agriculture and the challenges that face the agricultural system. By modifying our curricula now, we can provide today's students and tomorrow's leaders with the tools required to be successful. To do otherwise would be irresponsible.

But the question remains, who owns the curriculum? It is the faculty, and it is widely believed that faculties (I refer here to a faculty as a collective body) are not seriously addressing major curricular issues. We must reaffirm our commitment to caring for the total educational experience of our students, to see that they receive an education that will serve them well in the future. This education will provide a foundation in the basic life and physical sciences, in pure and applied mathematics, in courses that will provide for intellectual growth and problem-solving skills, an awareness of multicultural issues and diversity, and communication skills-oral, written, and interpersonal. If we do not assume responsibility for shaping the curriculum for the future, it could very likely result in a prescription curriculum mandated by our state legislatures, regents, or governing boards. Are we willing to take this risk, or shall we instead assume responsibility for the curriculum and move forward?

\section{Teaching}

More emphasis and reward need to be placed on teaching in much the same manner as research. The outstanding teacher and advisor should advance in salary and rank in the same fashion, and within the same time frames, as their counterparts in research. Unfortunately, this is usually not the case. There are, in fact, too few master teachers.

In actuality, the best teachers in a department should be given responsibility for the introductory courses to stimulate beginning students to explore our science of horticulture and to consider it as a major. This is generally not the case, as often the more junior members of the faculty, and therefore the least experienced, are called upon to teach the introductory courses.

Instruction must continue to be the first responsibility of the university community. This is not meant to downgrade or otherwise diminish our obligation to research, but rather to encourage more balance between rewarding excellence for performance in the classroom and at the research bench. Without a balance we risk further stratification of the faculty along responsibility lines, eventually resulting in a second-class citizenship for some, not an enlightened means to build strong departments. 


\section{THE NEW INTERNATIONAL DIMENSION}

As we re-assess and re-evaluate our land-grant universities we must also re-evaluate our traditional missions of research, instruction, and public service. We often fail to accept the fact that there is a fourth dimension-an international dimension-not to be viewed as a separate and equal mission, but rather as a dimension that requires full integration into our three traditional missions. This international dimension is far too important to set aside as a fourth wholly separate and definable mission, for in this fashion it will be dealt with only by those who wish to deal with it. We must view the international dimension as integral to our traditional mission.

At no time in history has it been more important for our students to have an understanding of the world. We need to incorporate international subject matter into our current courses. In the systematic review of course contents are we asking if students are being provided an international dimension? When our departments and colleges review curricula, do we seek evidence that students are gaining an understanding of international issues? Are we providing meaningful options for language study? Are we even encouraging language study? Do our general education requirements provide an international dimension for our students? Do we have viable, well-publicized opportunities for study abroad, international study tours, or work/study programs with international agendas? Are we really encouraging our students to take advantage of these opportunities?

Like our efforts to internationalize our resident instruction programs, we must realize that for many of us, the research function remains a critical part of our university mission. For today's research scientists to understand the international dimension of their work, they must fully understand and appreciate the issues society faces, and their work must be directed toward solutions that will work not only on the local level but in a world context. The United States is no longer the center for all research on those subjects we deem important. Clearly, we are among the world leaders in many, if not most, researchable areas, but we must remember that we are increasingly dependent on communication and collaboration with scientists throughout the world. We must ask if we are training future scientists (and we can ask the same of teachers and the agents of technology transfer) to have an understanding of global issues. Are we educating our graduate and undergraduate students, who will be the future technology transfer agents, so they are capable of producing the informational materials required to bring into focus the proper analytical perspectives in educating the public and political leadership? Do we have a plan, as we look to changes on our faculties, to hire those individuals who can develop an applied research and technology transfer program that will address complex international questions important to the producers of horticultural commodities?
Last, how do we fully incorporate this international dimension into our traditional tripartite land-grant mission? By and large, our faculty perceive that there are few rewards for participating in international activities. Rewards must be more than just a pat on the back. They must be viewed in the same way we view contributions that result from the laboratory or field, the successful transfer and adaption of new technologies, or the successful completion of a new course of instruction.

\section{A COMMITMENT TO THE FUTURE}

How many times have you heard the statement, "I'm not sure what it means to be a land-grant institution"? We must reaffirm our commitment to this principle, this experiment in higher education built with three fundamental and equal missions of instruction, research, and public service.

Are our land-grant universities still the engines of social change they were designed to be? Or have we lost our way and changed our basic mission and direction? Surely we have an obligation to conduct research and to generate new knowledge to be shared, but by becoming transformed into "research universities" and challenged by the lure of "big science," are we failing to serve the needs of the states that played a role in our creation and continue to provide a portion of our support?

Our institutional infatuation with size, as measured in R\&D dollar comparisons to our peers, is not unlike the Masai of East Africa, who measure their wealth in numbers of cattle. But does such counting say anything about the quality of the cattle or of the research?

Our land-grant universities should encourage basic research but basic research with a mission. We need to do more to encourage and support applied research that will meet the needs of the present. As we develop this new knowledge, we need to insure it is used, not locked away in journals in the library. Technology transfer is not accomplished simply by publishing a journal paper. That is just the first step in the process. This new knowledge belongs to the public, and to transfer this knowledge we need to pay renewed attention to our public service mission. Our special challenge for this decade will be to strengthen the linkage between the research, instruction, and technology-transfer missions of our land-grant universities, so that this new knowledge can be "extended" to those who truly own our land-grant universities-the citizens of our individual states. This is what makes these institutions-land-grant universities- so special and distinctive. 